Volume 1

July 2021

\title{
Covid-19 pandemic on youth tourism
}

Kübra Asan

Sinop University, kubra.asan@hotmail.com

Follow this and additional works at: https://digitalcommons.usf.edu/jometr

Part of the Hospitality Administration and Management Commons, and the Tourism and Travel Commons

\section{Recommended Citation}

Asan, K. (2021). Covid-19 pandemic on youth tourism. Journal of Mediterranean Tourism Research, 1(1), 12-21. https://www.doi.org/10.5038/2770-7555.1.1.1002

\section{Corresponding Author}

Kübra Asan, Sinop University, Department of Recreation Management, School of Tourism and Hotel Management, 57000 - Sinop, Turkey

\section{Revisions}

Submission date: May. 06, 2021; 1st Revision: May. 15, 2021; 2nd Revision: July 08, 2021; Acceptance: July. 27, 2021 


\title{
COVID-19 Pandemic on Youth Tourism
}

\author{
Kubra Asan \\ Department of Recreation Management, School of Tourism and Hotel Management, Sinop University, Turkey. \\ kubra.asan@hotmail.com
}

\begin{abstract}
The COVID-19 pandemic, which affected the entire world, has profoundly affected the tourism sector based on human mobility. However, it is estimated that the effects of the pandemic will be less in youth tourism. The study aims to explain the effects of the pandemic on the youth tourism market. In this context, a survey study was conducted in the InterRail Turkey Community/Unirail Group. The data collected by using the online survey technique were subjected to principal component analysis. After the analysis, it was seen that the effects of the pandemic on the tourism behavior of the participants can be explained in two dimensions as travel attitudes and preferences and hygiene and safety. Thus, the study concluded that the pandemic did not have a very high impact on travel attitudes and behaviors as well as hygiene and safety aspects. Also, the female participants were affected by the pandemic more than the male participants in terms of travel attitudes and preferences. As a result, despite the sharp decrease caused by the pandemic in general tourism mobility, there will be a more optimistic picture in youth tourism mobility if hygiene and security measures are taken.
\end{abstract}

Keywords: pandemic, COVID-19, young tourists, InterRail Turkey

\section{Introduction}

The COVID-19 virus, which started to be seen in Wuhan/China and spread rapidly and declared as a global pandemic by the WHO on $11^{\text {th }}$ March 2020 (WHO, 2020). Therefore, governments have tried to minimize the human mobility that caused the spread of the virus by taking restrictive measures to control the pandemic. On the other hand, the measures had profound negative effects on the economies of countries. In particular, the tourism and travel industry, which is based on human mobility, has been hit hard by the COVID-19 global pandemic (Aydın \& Doğan, 2021; Aydın et al. 2020; Gallego \& Font, 2020; Gössling et al., 2020; Lew et al., 2020; Williams \& Kayaoglu, 2020). International, regional, and local travel restrictions have brought international and national travel, daily visits, and air transport, and public transport to a standstill; festivals, meetings, and sporting events canceled or postponed (Gössling et al., 2020). More specifically, hospitality businesses and food and beverage businesses in the tourism sector in many countries, and service businesses that focus on cultural and entertainment production were temporarily closed (Williams \& Kayaoglu, 2020). The tourism industry was threatened by global pandemics before the COVID-19 outbreak. In the spring period of 2003, the SARS virus; Swine flu diseases the spring period of 2009 harmed tourism activity (Gallego \& Font, 2020). However, the COVID-19 outbreak was not limited to a certain region but brought global tourism mobility to a halt. UNWTO announced that international tourist arrivals decreased by $72 \%$ in 2020 . Despite the pleasing developments regarding the COVID-19 vaccine at the end of 2020, the effects of the pandemic 
continue. Social distancing, self-isolation, and restrictions are strictly enforced globally to prevent the pandemic (Kim et al., 2021).

As the pandemic restrictions continue, tourism academics have focused on the improvements, which reflected the understanding of tourism after the pandemic. Thus, it is claimed that instead of going back to the past, there will be a transformation in tourism practices in which the new practices and standards have been established based on public health and safety will be decisive (Ateljevic, 2020; Aydın et al. 2020; Galvani et al., 2020; Lew et al., 2020). This new transformation of tourism also offers opportunities to make new sustainable regulations to eliminate the negative effects of tourism (Ateljevic, 2020; Aydın \& Doğan, 2021; Galvani et al., 2020). Ateljevic (2020) supports the idea of transformational travel reflecting a personal meaning and purpose for the individual and appeals to motivations such as self-realization. In this regard, experiential travels are motivated and defined travel through a change in self-reflection and development and deeper communication with nature and culture (Trimble, 2017). The small-scale applicability of experiential travel is thought to support sustainable tourism. Thus, youth tourism is a type of tourism that should be evaluated in experiential and transformational travels context.

Youth tourism emerges with the tourist mobility of students, volunteers, language trainees, cultural exchange program participants, backpackers, and digital nomads. According to the World Youth Student \& Educational (WYSE) Travel Confederation, 23\% of international tourist arrivals are young people under the age of 30. Moreover, the youth tourism market generated almost USD 330 billion in tourism revenue in 2019 (WYSE, 2020a). As of 2020, there has been a sharp decline in the youth tourism market, as occurred in all tourism markets, due to the pandemic. On the other hand, it is predicted that the youth will take the lead in the travel movements (Aydın \& Doğan, 2020). Thus, young, single, middle class and experienced tourists participate in travel mobility by adapting more easily to current conditions (Chen et al., 2020).

The WYSE researches show that businesses offering experiential products such as camping activities, educational trips, language learning travels, and voluntary tourism have a relatively optimistic attitude towards the pandemic (WYSE, 2020b). Since it is not seasonal, the demand for youth tourism could be possibly spread to all year round. Moreover, some businesses point out that the pandemic may have a positive effect on youth tourism. So, volunteering and camping activities may increase accordingly. In this regard, young tourists are expected to be less affected by the COVID-19 pandemic. Based on this, the study aims to examine the effects of the COVID19 pandemic on the youth tourism market.

In the study, a survey research was conducted on the InterRail Turkey / Unirail Group by using an online platform and network to examine the effects of the COVID-19 pandemic on the youth market. The results of the study are expected to contribute to the youth tourism literature as well as the literature on the COVID-19 pandemic and its effects on youth tourism. Moreover, the study provides recommendations for tourism enterprises and policymakers targeting the youth tourism market. 


\section{Literature Review}

\section{Youth Tourism}

Youth tourism is a niche tourism market based on age. Youth tourism has emerged with the participation of young people in tourism activities for various purposes (İlbay \& Acar Gürel, 2015). According to the UNWTO (2008), youth travel includes all independent trips involved by people aged between 16-29 for a period of less than a year and their motivations in part or in full, by a desire to experience other cultures, build life experience and/or benefit from formal and informal learning opportunities outside one's usual environment.

Considering the youth tourism mobility, it is seen that young people tend to travel alone or with friends before getting married or starting a family (UNWTO, 2010). In this context, youth tourism has become a very popular tourism market that attracts the attention of many destinations and tourism businesses, since it eliminates the seasonality feature of tourism in general. For example, the Association of Turkish Travel Agencies (TÜRSAB) proposed the development of youth tourism which included the participation of 7-27 aged tourists (TÜRSAB, 2015).

Young tourists travel to explore different places and cultures, relax and have fun, visit friends and relatives, work, education, and language learning trips, and volunteer tourism activities (UNWTO, 2008). Young tourists, who usually organize their tour plans are observed to be prone to adventure. In addition to having fewer responsibilities as they have not yet started a family, young tourists do not look for much comfort in their destination and it is easier for them to be satisfied (Değişgel \& Bingöl, 2018). Moreover, young people rarely refrain from traveling because of political unrest, diseases, and natural disasters; they are pioneers in openning new interesting territories; they not only receive cultural benefits from travel but also contribute to the development of places they visit (UNWTO, 2008; Yunusovich, 2018).

In Turkey, youth tourism practices include government-sponsored projects under youth tourism (youth camps organized by the Ministry of Youth and Sports, European Voluntary Service Project, etc.,) as well as a small number of commercial business activities (İlbay \& Acar Gürel, 2015). Considering the increasing supply and demand in youth tourism, it is seen that youth tourism is a suitable type of tourism for sustainable development. Therefore, in the literature, the issue of youth tourism has an increasing interest (Yunusovich, 2018). The studies examining the potential of youth tourism in some destinations suggest youth tourism as an alternative type of tourism (Değiş̧gel \& Bingöl, 2018; İlbay \& Acar Gürel, 2015; Syzdykova et al., 2018; Tanrıverdi \& Öz, 2018).

Youth tourism has been affected by the pandemic as happened in all market segments of tourism. Although there are some social studies that examine youth-related issues during the pandemic process (Barbhuiva \& Mazmudes, 2021; Gordon et al., 2021) only a few studies focusing on youth tourism are available. For instance, Richards \& Morrill $(2021,2020)$ examined youth tourism businesses while the pandemic was continuing. According to these studies, youth tourism businesses experience different difficulties while tourism businesses in general face some other difficulties. For example, it is quite problematic to arrange social distance or reduce the capacity in hostel buildings where 4-12 people stay in a room or where social interaction areas occupy a large place. However, Richards \& Morrill (2021) pointed out that the youth travel industry is 
capable of more creative responses that can provide some mitigation, but the room for maneuver remains small. In addition to these studies focusing on the supply dimension of youth tourism, there is also need for studies examining the demand dimension. Thus, this study explores the attitudes and behavior changes of young tourists due to COVID-19 pandemic.

\section{Methods}

An online survey has carried out on the Unirail Facebook group which is a subgroup of InterRail Turkey to examine the behavioral effects of the COVID-19 pandemic on the youth tourism market. InterRail Turkey is a social media platform where many young travelers get together. On the platform, young people participating in activities such as backpacking, railway travel, volunteer tourism share their travel experiences or plans. Moreover, with their informational function, InterRail Turkey organizes non-commercial events such as camping events or social responsibility projects. InterRail Turkey has 362.7 thousand followers as of June 2020. After consultation with the administrators of the platform, data collection was allowed on the Unirail Facebook page, which is a subgroup of the platform. Unirail, which has 43.2 thousand members as of June 2020, is a very active group. In addition to travel information, homeworks and projects of university students and student club activities are shared in the group.

The data of the study were collected via an online questionnaire between $3^{\text {rd }}$ April 2020, and $22^{\text {nd }}$ May 2020, during the period of intense prohibition and restriction decisions for the COVID-19 outbreak. The impact scale developed by Wen et al (2005) after the SARS epidemic in China was used to explore the behavioral effects of the COVID-19 pandemic in tourism. This scale includes a 22-item with 3 factors named general effect, touristic attitude and behavior, hygiene and safety. An item on the consumption of wild animals as food in the scale was removed because it was not found to be meaningful in a cultural context. The questions were asked on a five-point Likert scale $(1$ = Strongly disagree, $2=$ Disagree, $3=$ Neither agree nor disagree, $4=$ Agree, $5=$ Strongly agree). Besides, the questions on age, gender, marital status, educational status, and travel purpose were also included in the questionnaire. The questionnaires were collected from 138 participants by simple random sampling method.

The data were taken into a preliminary evaluation before being analyzed. In this context, it has been determined that there is no missing data in the data set. Then, using the standardized $\mathrm{z}$ values, an outlier analysis was made. Values at a distance of 3.0 standard deviations from the mean were identified as an outlier and were removed from the data set (Alpar, 2011). Finally, skewness and kurtosis values were reviewed on 133 questionnaires, and normal distribution was examined. It was determined that kurtosis and skewness values in the data set were in the range of $-/+2$ and it was recorded that the data showed a normal distribution (Balanda \& Macgillivray, 1988).

The principal component analysis was performed to construct of validity in data analysis. The Kaiser-Meyer-Olkin (KMO) value of 0.882 was at a good level in the test performed to show that sufficient sample size was reached (Hair et al., 2010). Bartlett's test was conducted to determine the presence of statistically significant correlations between variables is significant $(\mathrm{p}=0.000)$. Additionally, Varimax rotation was used as the factor rotation method. For group comparison, the number of observations in the group must be at least 30 (Alpar, 2011). Therefore, analysis of differences could not be performed for other demographic variables. 
The study also aimed to examine the relationship between demographic characteristics and the effects of the pandemic on travel behavior. T-test and Pearson correlation tests were used to reveal the relationship between age and gender variables and the effects of the pandemic on travel behavior. The data analysis was made by using the SPSS 21 program.

\section{Results}

Firstly, the demographic characteristics of the participants were analyzed descriptively in the study (Table 1 below). The participants' ages range between 18 and 37 and the average age is 24 . The majority of the participants are female (57\%) and almost all of them are single (92\%). Their education status is quite high. Also, the participants were asked about the basic travel purposes based on the scale used by the World Tourism Organization (UNWTO, 2008) for the youth tourism market.

Table 1: Demographic Variables of the Participants

\begin{tabular}{|c|c|c|c|}
\hline Variable $(n=133)$ & $M$ & $n$ & $\%$ \\
\hline Age $\min =18 / \max =37$ & 24.5 & & \\
\hline \multicolumn{4}{|l|}{ Gender } \\
\hline Female & & 76 & 57.1 \\
\hline Male & & 57 & 42.9 \\
\hline \multicolumn{4}{|l|}{ Marital status } \\
\hline Single & & 123 & 92.5 \\
\hline Married & & 10 & 7.5 \\
\hline \multicolumn{4}{|l|}{ Education status } \\
\hline High school/equivalent or lower-level graduate & & 18 & 13.5 \\
\hline University graduate (associate degree and undergraduate) & & 90 & 67.7 \\
\hline Postgraduate graduate & & 25 & 18.8 \\
\hline \multicolumn{4}{|l|}{ Travel purpose } \\
\hline Discovering new places/cultures & & 86 & 64.7 \\
\hline Relax and have fun & & 30 & 22.6 \\
\hline Study abroad & & 4 & 3.0 \\
\hline Visiting friends and relatives & & 8 & 6.0 \\
\hline Work abroad & & 5 & 3.8 \\
\hline
\end{tabular}

Principal component analysis was applied for scale structure validity, which includes the behavioral effects of the COVID-19 pandemic in youth tourism. While applying the analysis, the attention has been paid to the rule that factor loads should be equal to or greater than 0.30 (Ho, 2006). Items with a factor load of less than 0.10 in more than one dimension were excluded from the analysis because they have co-morbid factor loads (Büyüköztürk, 2010). As a criterion of reliability, item-total correlation values that were required to be above 0.30 in item selection were examined (Tinsley \& Brown, 2000). Items not meeting these criteria were excluded from the analysis. As a result, a factor structure of 15 items with 2 factors was reached. The factors were named "travel attitudes and preferences" and "hygiene and safety" in keeping with the original scale. The explained variance rate is $62 \%$, which a satisfactory level (Çokluk et al., 2012). Besides, as seen in Table 2 below, the internal consistency rates, which are examined as a criterion of reliability, are also quite high.

The overall average of the participants agreeing with the statements about the impact of the pandemic on travel attitudes and preferences is 3.19 (Table 2 below). Accordingly, it is understood that the effect of the pandemic is not high on the travel attitude and preferences of the participants. On the other hand, the overall average of participants agreeing with the statements regarding the 
impact of the COVID-19 pandemic on the hygiene and safety dimension is 3.82 . In this context, the participants are relatively more affected by the pandemic in terms of hygiene and safety.

Table 2: Principal Component Analysis

\begin{tabular}{|c|c|c|c|c|c|c|}
\hline Item & $\begin{array}{l}\text { Variance } \\
\text { Explained }\end{array}$ & Eigenvalue & $\mathbf{M}$ & SD & $\begin{array}{l}\text { Item-Total } \\
\text { Correlation } \\
\end{array}$ & $\begin{array}{c}\text { Factor } \\
\text { Loadings }\end{array}$ \\
\hline Hygiene and safety $(\alpha=.910)$ & 7.57 & 50.47 & 3.82 & & & \\
\hline $\begin{array}{l}\text { I care more about the hygiene and safety of the } \\
\text { means of transportation after COVID- } 19 \text {. }\end{array}$ & & & 4.173 & 1.197 & .647 & .883 \\
\hline $\begin{array}{l}\text { I care more about the hygiene and safety of the } \\
\text { tourist sites after COVID-19. }\end{array}$ & & & 4.083 & 1.213 & .733 & .879 \\
\hline $\begin{array}{l}\text { Because of COVID-19, my interest in } \\
\text { participating in outdoor activities and eco- } \\
\text { tourism has increased }\end{array}$ & & & 4.098 & 1.186 & .772 & .807 \\
\hline $\begin{array}{l}\text { I care more about the hygiene and safety of the } \\
\text { daily necessities while traveling after COVID- } \\
19 .\end{array}$ & & & 3.992 & 1.203 & .719 & .800 \\
\hline $\begin{array}{l}\text { I care more about the hygiene and safety of the } \\
\text { hotels after COVID- } 19 \text {. }\end{array}$ & & & 4.075 & 1.216 & .683 & .786 \\
\hline $\begin{array}{l}\text { I care more about the health of the members in } \\
\text { the tour group after COVID- } 19 \text {. }\end{array}$ & & & 4.038 & 1.104 & .701 & .668 \\
\hline $\begin{array}{l}\text { In choosing tourist destinations, I will avoid } \\
\text { COVID-19 affected areas }\end{array}$ & & & 3.429 & 1.405 & .766 & .643 \\
\hline $\begin{array}{l}\text { I prefer to stay in high-quality star hotels after } \\
\text { COVID- } 19 .\end{array}$ & & & 2.647 & 1.220 & .400 & .451 \\
\hline Travel attitudes and preferences $(\alpha=.868)$ & 1.85 & 12.33 & 3.199 & & & \\
\hline $\begin{array}{l}\text { I will reduce the length of travel and tourism } \\
\text { after COVID-19. }\end{array}$ & & & 2.940 & 1.284 & .629 & .852 \\
\hline $\begin{array}{l}\text { I will greatly reduce my travel plans in the } \\
\text { next } 12 \text { months }\end{array}$ & & & 3.436 & 1.421 & .628 & .819 \\
\hline $\begin{array}{l}\text { I will avoid traveling to crowded big cities } \\
\text { after COVID-19. }\end{array}$ & & & 3.376 & 1.385 & .703 & .773 \\
\hline $\begin{array}{l}\text { I prefer suburbs or areas within a short } \\
\text { distance for leisure travel after COVID-19. }\end{array}$ & & & 3.233 & 1.290 & .634 & .721 \\
\hline $\begin{array}{l}\text { I prefer separated dining while traveling with a } \\
\text { tour group }\end{array}$ & & & 3.128 & 1.282 & .600 & .688 \\
\hline $\begin{array}{l}\text { Because of COVID-19, I believe traveling will } \\
\text { be unsafe. }\end{array}$ & & & 3.398 & 1.359 & .695 & .680 \\
\hline $\begin{array}{l}\text { I prefer traveling with family members and } \\
\text { relatives after COVID- } 19 \text {. }\end{array}$ & & & 2.880 & 1.354 & .469 & .464 \\
\hline Total $(\alpha=.926)$ & 62.79 & & & & & \\
\hline
\end{tabular}

For the study, the impacts of the COVID-19 pandemic on the participants and demographic variables was examined. In this context, the results of the t-test applied to reveal the pandemic impacts according to the gender variable are shown in Table 3 below. According to the analysis results, it was seen that the gender variable has a statistically significant difference in the dimension of travel attitudes and preferences $(p<0,05)$. The male participants are less affected by the pandemic compared to the female, and the pandemic's impact level on their travel attitudes and preferences are relatively lower. In terms of hygiene and safety, participants are moderately affected by the pandemic, regardless of their gender. 
Table 3: COVID-19 Pandemic Impacts by Gender

\begin{tabular}{lcccccc}
\hline Factor & Gender & $\boldsymbol{n}$ & $\mathbf{M}$ & SD & $\begin{array}{c}\text { T- } \\
\text { Value }\end{array}$ & $\boldsymbol{p}$ \\
\hline Hygiene and safety & Female & 76 & 3.89 & .94 & 1.552 & .123 \\
Travel attitudes and & Male & 57 & 3.63 & .93 & & \\
preferences & Female & 76 & 3.35 & .94 & 2.045 & $\mathbf{. 0 4 3}$ \\
& Male & 57 & 2.99 & 1.08 & & \\
\hline
\end{tabular}

Correlation analysis was applied to reveal the relationship between the effects of the COVID-19 pandemic on the participants and the age variable (Table 4 below). According to the analysis, it was found that the age variable has a positive and significant relationship with both factors ( $\mathrm{p}<$ 0,05 ). Thus, as the age increases, the participants have stricter attitudes in terms of both hygiene and safety, and travel attitudes and preferences.

Table 4: COVID-19 Pandemic Impacts by Age

\begin{tabular}{lcccc}
\hline Factor & M & SD & $\boldsymbol{r}$ & $\boldsymbol{p}$ \\
\hline Hygiene and safety & 3.19 & 1.019 & .68 & $\mathbf{0 . 0 0 0}$ \\
Travel attitudes and preferences & 3.78 & .94 & .67 & $\mathbf{0 . 0 0 0}$ \\
\hline
\end{tabular}

\section{Conclusion}

This study has surveyed InterRail Turkey / Unirail group that is one of the largest online platforms of young tourists in Turkey in order to understand the effect of the COVID-19 pandemic on the youth market. As a result of the analysis of the data collected online during the period when the pandemic measures were most intense, some findings were obtained regarding the effects of the pandemic on young tourists. Therefore, it was seen that the pandemic did not have a major impact on young tourists' travel attitudes and preferences, as well as their hygiene and safety attitudes. This finding indicates that there will not be a big decrease in the travel mobility of young people in the post-pandemic period. On the other hand, in terms of hygiene and safety, the pandemic can relatively affect the travel behavior of the participants. Thus, it is estimated that young tourists will be relatively more sensitive about hygiene and safety in their travels.

The results of the study support the sector analysis of the WYSE Travel Confederation (2020b). Accordingly, young tourists will be willing to start traveling again by paying attention to the hygiene and safety dimension after the pandemic measures and travel restrictions are over. Especially youth tourism practices, which do not have a seasonal limitation, can be effective in creating a tourism activity throughout the year.

On the other hand, as Richards and Morrill (2020) stated, youth tourism businesses are struggling with many general and specific challenges due to the pandemic. At this point, youth tourism businesses should be supported by governments to overcome the pandemic challenges. Although no serious changes are expected in young tourists' attitudes and preferences at post-pandemic travel, the travel obligations such as to be vaccinated or take the COVID-19 test may shape the international mobility of young tourists. Especially in developing countries with limited access to vaccines, young people, who are already in the low-risk group, may not be able to participate in international travels because it is difficult for them to be vaccinated. At this point, governments may introduce applications such as free vaccination and test for young people traveling with education, language learning, or voluntary purposes in post-pandemic tourism. 
In tourism, it is very important to reduce the negative effects in the post-pandemic period and to adopt more sustainable practices, especially in socio-economic terms. Lew et al. (2020) state that in the post-pandemic period, policy-makers will be determinant in tourism, especially to transform tourism and reach sustainable tourism forms. In this context, policy-makers are expected to produce plans and policies that will create environments in which tourists safely participate in tourism mobility. Standards are developed to cover tourism practices in public health and hygiene.

Youth tourism is a more sustainable form of tourism compared to mass tourism. Characteristics such as year-round demand and small-scale applicability make youth tourism sustainable. In this context, incentives can be introduced for businesses that will enter into the youth market. Facilitating practices can be used for young tourists to participate in travel mobility. Especially for university students, student mobility programs can be expanded, besides convenience in passport procedures or special visa applications can be introduced.

The youth market can divide into various niche markets due that it contains the experiential elements. Thus, more sustainable forms of tourism can be built by moving away from mass tourism movements. Also, niche or micro-niche markets will provide a competitive advantage for tourism businesses that will develop expertise in these fields. Tourism businesses that will operate in the youth tourism market can benefit from the relational marketing approach. In this context, mobile communities such as InterRail Turkey are effective on communication platforms and networks. These platforms, where young people are very eager to express themselves and their experiences, are important in terms of promotion channels as well as sources of market information. Moreover, businesses can develop new products whose target audience is ready to involve in co-creative processes with these platforms. Besides, young travel bloggers, YouTubers, and Instagrammers can be successful business partners for tourism businesses within the scope of influencer marketing. Therefore, it is recommended that businesses should develop and customize their business process on these new medias.

The study contains limitations since it was applied with a limited sample. It was assumed that the members of the Unirail Facebook group who participated in the survey of the study are potential or effective young tourists. Future studies can be carried out with a sample of effective young tourists. Another limitation of the research is that it is planned and implemented in a short period. In this context, a scale developed in China after the SARS virus was used to explain the pandemic impacts. More comprehensive scale development studies are needed on the effects of the COVID19 pandemic on tourist behavior. Also, there was a complex country and world agenda that progressed rapidly during the pandemic period in which the study was conducted. In addition to rapidly implemented measures (or decision changes in measures), the spoiling of information from very different and unreliable sources can create uncertainty or complexity in individuals' perceptions and attitudes. In this context, the observable effects of the pandemic on tourist behavior can be better explained by studies that will be carried out in the post-pandemic periods.

\section{References}

Alpar, R. (2011). Uygulamalı çok değişkenli istatiksel yöntemler [Applied Multivariate Statistical Methods]. Detay. Ateljevic, I. (2020). Transforming the (tourism) world for good and (re)generating the potential 'new normal, Tourism Geographies, 22(3). doi:10.1080/14616688.2020.1759134.

Aydın, B., \& Doğan, M. (2020). Yeni Koronavirüs (COVID-19) pandemisinin turistik tüketici davranışları ve Türkiye turizmi üzerindeki etkilerinin değerlendirilmesi [Evaluation of Effects of the COVID-19 Pandemic 
on Touristic Consumption Behavior and Tourism in Turkey]. Pazarlama Teorisi ve Uygulamaları Dergisi., 6(1), 93-115.

Aydın, B., Arıca, R., \& Arslantürk, Y. (2020). The Effect of Novel Coronavirus (COVID-19) on Travel Risk Perception. Journal of Yasar University, 16(61), 378-392.

Balanda, K. P., \& Macgillivray, H. L. (1988). Kurtosis: A critical review. The American Statistician, 42(2), 111-121. https://doi.org/10.2307/2684482

Barbhuiya F., \& Mazmuder, A. G. (2021). Transformation of a recreational youth group into community service group during the COVID-19 pandemic, Social Work with Groups, 44(1), 53-59.

Büyüköztürk, Ş. (2010). Sosyal bilimler için veri analizi el kitabı [Manual of data analysis for social sciences] Pegem.

Chen, K., Enger, W. Yu, J., \& Zhang. C. (2020, 12 May). Hitting the road again: How Chinese travelers are thinking about their first trip after COVID-19. McKinsey. https://www.mckinsey.com/businessfunctions/marketing-and-sales/our-insights/a-global-view-of-how- consumer-behavior-is-changing-amidCOVID-19.

Çokluk, Ö., Şekercioğlu, G., \& Büyüköztürk, Ş. (2012). Sosyal bilimler için çok değişkenli istatiksel SPSS ve Lisrel Uygulamalart [Multivariate Statistical SPSS and Lisrel Applications for Social Sciences]. Pegem.

Değişgel, S., \& Bingöl, Z. (2018). Şanlıurfa ilinin gençlik turizmi potansiyelinin incelenmesi [Investigation of Youth Tourism Potential of Şanlıurfa Province] Uluslararası Toplum Araştırmaları Dergisi, 8(8), 375-390.

Gallego, I., \& Font, X. (2020). Changes in air passenger demand as a result of the COVID-19 crisis: Using big data to inform tourism policy, Journal of Sustainable Tourism, 29(9), 1-20. doi:10.1080/09669582.2020.1773476.

Galvani, A., Lew, A. A., \& Perez, M. S. (2020). COVID-19 is expanding global consciousness and the sustainability of travel and tourism. Tourism Geographies, 22(3), 567-576. doi:10.1080/14616688.2020.1760924.

Gordon, F., Klose H., \& Storrod, M. L. (2021). Youth (in)justice and the COVID-19 pandemic: Rethinking incarceration through a public health lens, Current Issues in Criminal Justice, 33(1), $27-46$.

Gössling, S., Scott, D., \& Hall, C. M. (2020). Pandemics, tourism and global change: A rapid assessment of COVID-19. Journal of Sustainable Tourism, 29(1), 1-20. doi:10.1080/09669582.2020.1758708.

Hair, J. F., Black, W., Babin, B., \& Anderson, R. (2010). Multivariate data analysis. Pearson Education.

Ho, R. (2006). Handbook of univariate and multivariate data analysis and interpretation with SPSS. Chapman and Hall.

İlbay, B., \& Acar Gürel, D. (2015). Gönüllü ve gençlik turizminin birlikte ele alınması: Eskişehir'e yönelik bir öneri [Joining together the volunteer and the youth tourism: An implication for Eskişehir/Turkey] International Journal of Human Science, 12(2), 207-234.

Kim, J., Kim, J., \& Wang, Y. (2021). Uncertainty risks and the strategic reaction of restaurant firms amid COVID19: Evidence from China, International Journal of Hospitality Management, 92, 1-11.

Lew, A. A., Cheer, J. M., Haywood, M., Brouder, P., \& Salazar, N. B. (2020). Visions of travel and tourism after the global COVID-19 transformation of 2020, Tourism Geographies, 22(3), 455-466. doi:10.1080/14616688.2020.1770326.

Richards, G., \& Morrill, W. (2020). The impact and future implications of COVID-19 in the youth travel sector, Atlas Review, 2, 57-64.

Richards, G., \& Morrill, W. (2021). The challenge of COVID-19 for Youth Travel. Revista Anais Brasileiros De Estudos Turísticos/ ABET, 11, 1-8.

Syzdykova, A., Abubakirova, A., \& Bingöl, Z. (2018 27 June-01 July). Gençlik turizminin küresel düzeyde değerlendirilmesi. [Conference Presentation] III. International Congress of Youth Researches Congress, Nahcivan, Azerbaijan. https://docplayer.biz.tr/105219310-Iii-international-congress-of-youth-researchescongress-book-27-june-01-july-2018.html

Tanrıverdi, H., \& Öz, M. (2018 27 June-01 July). Kültürel miras unsurlarından Kaşenlik Adeti’nin gençlik turizmi kapsaminda incelenmesi. [Conference Presentation] III. International Congress of Youth Researches Congress, Nahcivan, Azerbaijan. https://docplayer.biz.tr/105219310-Iii-international-congress-of-youthresearches-congress-book-27-june-01-july-2018.html

Tinsley, E. A., \& Brown, S. D. (2000) Handbook of applied multivariate statistics and mathematical modeling. Academic.

Trimble, M. (2017). Why transformative travel will be the travel trend of 2017. Vogue. https://www.vogue.com/article/transformative-travel-trend-2017.

TÜRSAB- Association of Turkish Travel Agencies (2015). TÜRSAB Gençlik Turizmi 2015 Raporu. Türsab. https://www.tursab.org.tr/apps/OldFiles//dosya/12191/tursab-genclik-turizmi-2015 raporu117755463808_12191_560578.pdf. 
UNWTO- World Tourism Organization. (2008). Youth travel matters understanding the global phenomenon of youth travel. UNWTO.

UNWTO- World Tourism Organization. (2010). Demographic Change and Tourism. UNWTO.

UNWTO- World Tourism Organization. (2020). Internatıonal Tourst Numbers Could Fall 60-80\% In 2020, UNWTO Reports. UNWTO. https://www.unwto.org/news/COVID-19-international-tourist-numbers-couldfall-60-80-in-2020.

Wen, Z., Huimin, G., \& Kavanaugh, R. R. (2005). The impacts of SARS on the consumer behaviour of Chinese domestic tourists. Current Issues in Tourism, 8(1), 22-38. doi:10.1080/13683500508668203.

WHO- World Health Organization. (2020, 11 March). WHO director-general's opening remarks at the media briefing on COVID-19. Who.Int. https://www.who.int/dg/speeches/detail/who-director-general-s-openingremarks-at-the-media-briefing-on-COVID-19---11-march-2020.

Williams, C. C., \& Kayaoglu, A. (2020). COVID-19 and undeclared work: Impacts and policy responses in Europe. The Service Industries Journal, 40 (13-14), 914-931, doi:10.1080/02642069.2020.1757073.

WYSE Travel Confederation (2020a). COVID-19 travel business impact series. Wysetc.

https://www.wysetc.org/wp-content/uploads/sites/19/2020/09/WYSE_COVID19_Travel_Business_Impact_Series_August.pdf .

WYSE Travel Confederation (2020b). Youth travel anticipating 30\% Decrease in Business for 2020. Wysetc. https://www.wysetc.org/2020/03/COVID-19-travel-business-impact-series-part-1/ .

Yunusovich, S. S. (2018). Youth tourism as a scientific research object, Journal of Tourism \& Hospitality, 7(5), 1-3.

\section{Acknowledgment}

This study was presented at the Conference on Managing Tourism Across Continents (MTCON2020). The research, published as a summary in the proceedings book, has been presented in this article by increasing the sample size and improving it. 